\title{
'Mars mania' and the right to celebrate
}

Whether there is life on Mars or not, the public response to last week's findings from meteorite ALH84001 should serve to remind scientists why they do what they do.

THE space science community has just enjoyed one of the finest weeks imaginable, basking in the reflected glory of a result that tentatively suggests that there was once life on Mars - capped by a ringing endorsement of its work delivered by an ebullient US president on the White House lawn. Yet parts of the community respond as though they had just been mugged.

Scientists of many disciplines are sceptical about the evidence presented by McKay et al., no single strand of which is either conclusive or even unique. People from the US National Science Foundation's Antarctic Program - which found the rock - and other scientists related to the project feel usurped by the typically brazen manner in which the National Aeronautics and Space Administration (NASA) has sought to take all the credit for itself. Stephen Jay Gould, writing in Sunday's New York Times, points out that the result comes as no surprise to palaeontologists such as himself and asks, in effect, what all the fuss is about.

What is all the fuss about? The paper to be published tomorrow in Science presents several separate strands of evidence and argues that, in combination, they "could be fossil remains of past Martian biota". Individually, the different strands do not amount to much (see pages 575-576) but, the authors say, "when they are considered collectively, particularly in view of their spatial association, we conclude that they are evidence for primitive life on early Mars".

At which point, enter Dan Goldin, NASA's rhetorically gifted administrator. Goldin has a treacle-filled yarn for every occasion: on 7 August, the grandest one of all, he told the world's media of a telephone conversation the previous evening with his ailing father in Florida. If nothing else, he said, the pending announcement of this scientific discovery had lifted his father's spirits.

For once, Goldin's story rings perfectly true - and that is what all the fuss is about. The entire population is gripped in fascination by the contents of this piece of rock - especially the very young and very old, less absorbed than the rest of us in the daily banalities of earning a living. Their fascination runs through all the generations, from the eight-year-old child who earnestly informed the CNN television channel that the paper cannot be right, because the meteorite came from the wrong part of the Red Planet (how he knew this is unrecorded) to Dan Goldin's father.

Modern science is nothing more nor less than the operating arm of the population's insatiable curiosity. This may seem obvious, but, from some of the ways science has been trying to sell itself of late, one would never guess as much. Bereft of its alleged former mission of fighting the Cold War, it is most often presented as a means of fighting an imaginary economic war between various countries that are demonstrably at peace with one another and whose economies are mutually dependent. On other days, science is pitched (not very convincingly) as a route to cheaper health care, or as the saviour of an overstressed global ecosystem.

With the demise of the corporately funded basic research laboratory and of the Soviet Union, virtually all scientific research is now paid for by the public, through its elected representatives. The public should pay for science because the people want to explore the frontiers of knowledge. If the people ever tire of such exploration - or if their tedious yearnings are beneath the consideration of scientists - then the funding should cease. But even in this jaded age, last week's events show that the public's curiosity is as vibrant as ever.

So what if there has been no life on Mars, and the expectations raised in every corner of this planet by the McKay et al. paper are gradually deflated by further study? Then we will still be left to ponder the response of the people (pursued breathlessly by politicians and the press) to the possibility of progress, and a timely reminder of what science is for. As Margaret Thatcher once said: "Rejoice".

\section{The resignation tool}

The mass resignation of advisers to the board supposed to regulate air pollution in Los Angeles sets a good example.

NINE out of eleven members of the scientific advisory panel to the South Coast Air Quality Management District (AQMD) in California resigned last week (see page 567). They concluded that, with the recent publication of a peculiarly limp air pollution management plan for the Los Angeles area, their advice had been ignored once too often.

Their principled stand may not reverse the AQMD's policies, which are based on the notion that even if the air in Los Angeles is the dirtiest in the United States, further regulation would do unnecessary harm to the local economy. But, by taking a stand, the nine set a fine example for members of other scientific advisory boards. All too often in this type of situation, such panels sit uneasily in silence, lending false credibility to the inept policies of the bodies they advise.

Western politicians have lost the resignation habit: since Lord Carrington resigned as UK foreign secretary in 1982, over mistakes made by his subordinates in the run-up to the Falklands conflict, no British minister has resigned on a matter of principle, and in the United States the concept is almost entirely forgotten. Donna Shalala, the health secretary, for example, is deeply opposed to the welfare bill which President Bill Clinton has recently agreed to sign, but the question of her resignation has not arisen. As politicians have forgotten when to resign, the public, oddly enough, has forgotten to hold them in any kind of esteem.

Scientists should be wary of falling into the same trap. The more eminent are increasingly enmeshed in a web of advisory boards, especially in the United States, and service seems a virtual obligation for some. But the boards can be too close by half to the agencies that they advise.

In southern California, the efforts of local politicians to extract the teeth of the AQMD had gone too far, and it was time for the environmental scientists, doctors and economists on the advisory panel to call it quits. In doing so, they have scored an immediate success in drawing public attention to the AQMD's policies. They also remind all of us that resignation is sometimes the only adequate declaration of independence. 